\title{
HOMENAGEM PÓSTUMA
}

1971.

Faleceu em Roma, Itália, o Professor Ettore Onorato, aos 31 de outubro de

O Professor Ettore Onorato, que desaparece aos 73 anos de idade, teve uma existência inteiramente dedicada ao ensino e à pesquisa científica, sobressaindo-se como grande mestre pelas qualidades didáticas excepcionais e como pesquisador e orientador, pela meticulosidade, argúcia, precisão e energia.

O Professor Onorato iniciou sua carreira universitária como assistente na Universidade de Roma, tendo estagiado na Inglaterra durante vários anos como discípulo de Bragg e na Alemanha, como discípulo de Schoenflies e Sohncke, eminentes cristalógrafos alemães. Na Alemanha, teve oportunidade de conviver como colega de Shubnikov, cristalógrafo russo, também recentemente desaparecido. Posteriormente, Onorato foi indicado, por concurso, ao cargo de Professor Ordinário da Universidade de Sardenha, Itália, aos 35 anos de idade, de onde se transferiu provisoriamente ao Brasil, como Professor Catedrático Visitante na recém-criada Universidade de São Paulo, fundada por Armando de Salles Oliveira.

Aqui Onorato fundou e criou o nosso Departamento de Mineralogia e Petrologia, e de certo modo, a longo prazo, o Instituto de Geociências, formando uma escola de mineralogistas e cristalógrafos brasileiros.

Onorato permaneceu entre nós como professor durante quatro anos, tendo realizado porém uma obra científica equivalente a um período bem maior, pelo entusiasmo e energia com que sabia conduzir os seus trabalhos de pesquisa, de administração, organização e orientação de discípulos .

Mesmo longe de nós, após seu regresso a Itália, já como Professor Ordinário na Universidade de Roma, o mais alto posto científico do país, Onorato não perdeu o contacto com seus antigos discípulos brasileiros, atravez de correspondência constante e por viagens periódicas que realizava ao Brasil.

Agradecemos a obra que Onorato realizou por nós brasileiros, deixando aqui a nossa saudade perene e rendendo a nossa homenagem póstuma a tão insigne professor, cientista, homem de bem e amigo.

William Gerson Rolim de Camargo 


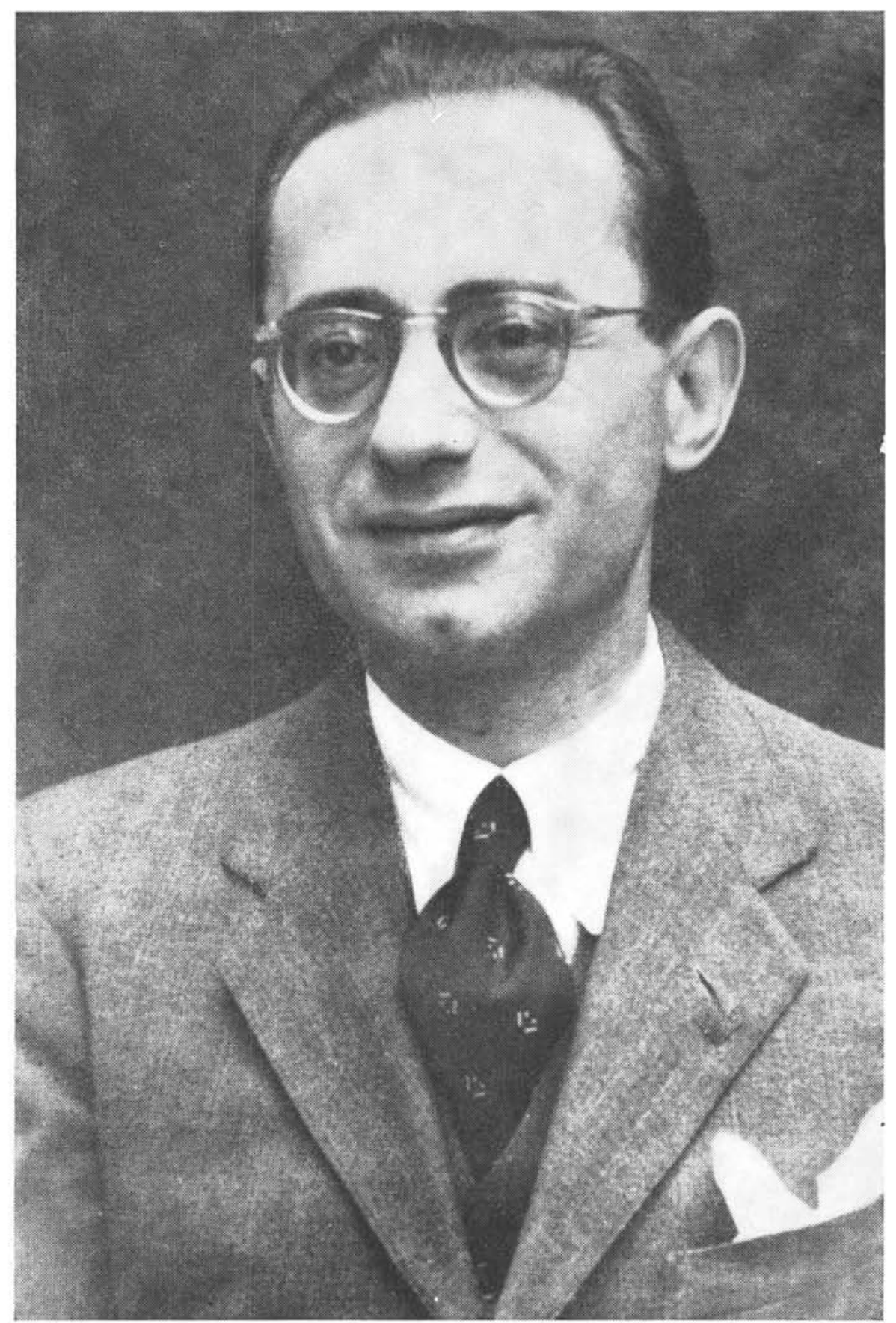

PROFESSOR ETTORE ONORATO (1898-1971) 